\title{
Prevalence of anemia in adolescent girls - A cross sectional study from Karnataka
}

\author{
Radhika C Mekale ${ }^{1 *}$, Rita D², Anant A Takalkar ${ }^{3}$
}

${ }^{1}$ Postgraduate Student, 2Professor And Head, Department of Obstetrics \& Gynaecology, Navodaya Medical College and Hospital, Raichur, INDIA.

3Professor In Community Medicine, MIMSR Medical College and YCR Hospital, Latur, Maharashtra, INDIA.

Email: radhikacm999@gmail.com

\begin{abstract}
Background: Anemia is a condition characterized by reduction in the number of red blood cells and/or hemoglobin (Hb) concentration. Anemia is a global public health problem affecting both developing and developed countries and has major consequences for human health as well as social and economic development. Objectives: To study the prevalence and sociodemographic correlates of anemia among Adolescent (13-19 years) girl students Methodology: The present study cross sectional study was conducted among 200 adolescents (13 - 19 years) girls studying 8 std -12std in government school Raichur. The data collected was entered in Microsoft excel and analyzed using epi-info software and SPSS trial version 17. Results: Mild anemia (Hb 11 - 11.9gram percent) was present in $8(16 \%)$ girls, moderate anemia (Hb 7 - 10.9 gram percent) in $37(74 \%)$ girls and severe anemia ( $\mathrm{Hb}<7$ gram percent) in $5(10 \%)$ girls. About $116(58 \%)$ were between 1719 years of them 28 ( $24.2 \%$ ) had anemia. There was association between anemia and socioeconomic status, anemia and type of family in our study. $32 \%$ had illiterate father compared to $68 \%$ literate father with p value 0.034 (which is not statically significant), but majority of them i.e $84 \%$ had illiterate mother and only $16 \%$ had literate mother. Conclusion: Anemia prevalence is noted in our study as $25 \%$ with moderate anemia as $74 \%$. Microcytic hypochromic anemia $60 \%$ was noted followed by normocytic normochromic 30\%, macrocytic normochromic $10 \%$. High risk factors were students belonging to low socio - economic groups.
\end{abstract}

*Address for Correspondence:

Dr Radhika C Mekale, Postgraduate Student, Department of Obstetrics \& Gynaecology, Navodaya Medical College And Hospital, Raichur, India.

Email:

Received Date: 09/04/2020 Revised Date: 06/06/2020 Accepted Date: 12/07/2020

DOI: https://doi.org/10.26611/10121531

This work is licensed under a Creative Commons Attribution-NonCommercial 4.0 International License. (cc) EY-NC

\begin{tabular}{|l|l|}
\hline \multicolumn{2}{|c|}{ Access this article online } \\
\hline Quick Response Code: & Website: \\
\hline & www.medpulse.in \\
\cline { 2 - 3 } & \\
\end{tabular}

\section{INTRODUCTION}

The word Adolescence is derived from a Latin word "adolescere" which means "to grow". WHO defines Adolescent as a person between 10 and 19 years of age. ${ }^{1}$ There are 1.2 billion adolescents $(10-19$ years $)$ worldwide $^{2}$ and India is home to the largest national population of adolescents ( 243 million), followed by China (207 million), the United States (44 million), Indonesia, and Pakistan (both 41 million each). ${ }^{3}$ World health organization also defines Adolescent as a transitional period phase of growth and development between childhood and adulthood. ${ }^{4}$ Adolescence is a crucial period in life of every individual, during which there is a transition from childhood to adulthood. This period is characterized by rapid physical, biological, and hormonal changes resulting in psycho-social, behavioral changes and sexual maturity in an individual. It is the second growth spurt of life, and both boys and girls undergo different experiences in this phase. ${ }^{5,6}$

Anemia is a condition characterized by reduction in the number of red blood cells and/or hemoglobin $(\mathrm{Hb})$ concentration. ${ }^{7}$ Anemia is a global public health problem affecting both developing and developed countries and has major consequences for human health as well as social and 
economic development. It affects $24.8 \%$ of the world population. ${ }^{8}$ The burden of anemia varies with a person's age, sex, altitude, and pregnancy. ${ }^{7}$ The worldwide prevalence of anemia among adolescents is $15 \%(27 \%$ in developing countries and $6 \%$ in developed countries). ${ }^{9}$ Objectives:

To study the prevalence and sociodemographic correlates of anemia among Adolescent (13-19 years) girl students

Source of data: The present study was conducted among 200 adolescents $(13-19$ years $)$ girls studying 8 std -12 std in government school Raichur, with the aim of finding prevalence of anemia and associated risk factors

Study design: Cross - sectional study

Study area: Government school girls - Raichur

Study population: Adolescent (13 - 19 years) girl students

Sample size: 200

Calculated using the formula, $\mathrm{N}=4 \mathrm{pq} / \mathrm{L}^{2}$

(Where $\mathrm{N}=$ Sample size, $\mathrm{p}=$ prevalence of the condition, $\mathrm{q}=100-\mathrm{p}, \mathrm{L}=$ allowable error, taken as 5 here)

From the recent study in Karnataka, prevalence of anemia among adolescents was $89 \%$

Hence $\mathrm{N}=4$ X 89 X $11 / 5$ X 5

$=3916 / 25$

$=157$

It was rounded off to 200 including a non - response rate of $20 \%$.

Hence the total sample size is taken as $\mathbf{2 0 0}$

Inclusion criteria:

1. Adolescent girls aged $13-19$ years

Exclusion criteria:

1. girls who were unavailable for data collection during 3 consecutive visits

2. Those girls who did not consent for the study.
Data collection:

$>$ The study is conducted after taking Ethical community clearance, consent from the government school principal.

$>$ Counselling was done first, after that proforma were given to the students.

$>$ A predesigned pretested Proforma was used to collect data. It contained identification details, socio - demographic details and clinical details.

- Proforma was given to the students which contained the questioners regarding the sociodemography and clinical factors associated with anemia, it was explained in verbal language, then students were asked to complete it and completed proforma was taken for analysis.

- Statistical plan: The data collected was entered in Microsoft excel and analyzed using epi-info software and SPSS trial version 17. The categorical variables are expressed as percentage and relation between two categorical variables are analyzed using $\mathrm{Chi}$ - square test.

\section{RESULTS}

\begin{tabular}{lcc}
\multicolumn{3}{c}{ Table 1: Prevalence of anemia } \\
\hline Parameters & Number of cases & Percentage \\
\hline Mild anemia & 8 & $16 \%$ \\
Moderate anemia & 37 & $74 \%$ \\
Severe anemia & 5 & $10 \%$ \\
\hline
\end{tabular}

Anemia was present in $50(25 \%)$ of the study participants. Mild anemia (Hb $11-11.9$ gram percent) was present in 8 (16\%) girls, moderate anemia ( $\mathrm{Hb} 7-10.9$ gram percent) in $37(74 \%)$ girls and severe anemia $(\mathrm{Hb}<7$ gram percent $)$ in $5(10 \%)$ girls.

Table 2: Comparison of socio - demographic factors associated with anemia

\begin{tabular}{|c|c|c|c|c|c|}
\hline Factors & $\begin{array}{c}\text { Number }(\mathrm{N}=200) \\
(\%)\end{array}$ & $\begin{array}{c}\text { Anemia (N = 50) } \\
(\%)\end{array}$ & No anemia $(\mathrm{N}=150)(\%)$ & $\begin{array}{c}\text { Chi - square } \\
\left(\chi^{2}\right)\end{array}$ & 'P' value \\
\hline Age :- $13-16$ & $84(42 \%)$ & $22(26.2 \%)$ & $62(73.8 \%)$ & 7.111 & 0.328 \\
\hline years & $116(58 \%)$ & $28(24.2 \%)$ & $88(75.8 \%)$ & & \\
\hline \multicolumn{6}{|l|}{$17-19$ years } \\
\hline Education :- 8std & $24(12.0 \%)$ & $04(16.6 \%)$ & $20(83.4 \%)$ & & \\
\hline 9std & $35(17.5 \%)$ & $12(34.2 \%)$ & $23(65.8 \%)$ & 2.642 & 0.852 \\
\hline 10std & $42(21.0 \%)$ & $16(38.1 \%)$ & $26(61.9 \%)$ & & \\
\hline 11 std & $55(27.5 \%)$ & 09 (16.4\%) & $46(83.6 \%)$ & & \\
\hline $12 s t d$ & $44(22.0 \%)$ & $09(20.5 \%)$ & 35 (79.5\%) & & \\
\hline Religion :- Hindu & $165(82.5 \%)$ & $44(26.7 \%)$ & $121(73.3 \%)$ & & \\
\hline Muslim & $17(08.5 \%)$ & $03(17.6 \%)$ & $14(82.4 \%)$ & 1.401 & 0.496 \\
\hline Christian & $18(09.0 \%)$ & $03(16.7 \%)$ & $15(83.3 \%)$ & & \\
\hline
\end{tabular}

About $116(58 \%)$ were between 17-19 years of them 28 ( 24.2\%) had anemia and 84(42\%) were between 13-16 years of them $22(26.2 \%)$ had anemia , and P value was not found statistical significant. About $24(12 \%)$ girls were studying in 8std out of which 4 ( $16.6 \%)$ had anemia and 35(17.5\%) were studying in 9std of which $12(34.2 \%)$ had anemia. About $42(21 \%)$ girls were studying in $10^{\text {th }}$ std of which $16(38.1 \%)$ had anemia and $55(27.5 \%)$ girls were studying in $11^{\text {th }}$ class 
out of them $9(16.4 \%)$ had anemia and $44(22 \%)$ in $12^{\text {th }}$ class of which $9(20.5 \%)$ had anemia , P value was not found statistical significant, may be because of small number

- Majority of the girls were Hindus, 165 (82.5\%) while 18 (9\%) were Christians and 17 (8.5\%) were Muslims, no correlation of anemia with religion was noted in our study (No significant $p$ value)

\begin{tabular}{|c|c|c|c|c|c|}
\hline Factors' & $\begin{array}{c}\text { Number of cases } \\
(\mathrm{N}=\mathbf{2 0 0})\end{array}$ & $\begin{array}{c}\text { Anemia } \\
(\mathrm{N}=50)\end{array}$ & $\begin{array}{l}\text { No anemia } \\
(\mathrm{N}=150)\end{array}$ & $\begin{array}{l}\text { Chi value } \\
\text { square }\left(\chi^{2}\right)\end{array}$ & $P$ value \\
\hline \multicolumn{6}{|l|}{ Socio - economic status } \\
\hline Upper class- I & $01(00.5 \%)$ & $00(0)$ & $01(100.0)$ & \multirow{5}{*}{14.281} & \multirow{5}{*}{0.006} \\
\hline Upper middle class -II & $40(20.0 \%)$ & $08(20.0 \%)$ & 32 (80.0\%) & & \\
\hline Lower middle class-III & $55(27.5 \%)$ & 06 (10.9\%) & 49 (89.1\%) & & \\
\hline Upper lower class- IV & $78(39.0 \%)$ & $24(30.8 \%)$ & $54(69.2 \%)$ & & \\
\hline Lower class - V & $26(13.0 \%)$ & $12(46.2 \%)$ & $14(53.8 \%)$ & & \\
\hline \multicolumn{6}{|l|}{ Type of family } \\
\hline Nuclear & $130(65.0 \%)$ & 19 (14.6\%) & $111(85.4 \%)$ & \multirow{3}{*}{21.848} & \multirow{3}{*}{0.000} \\
\hline Joint & $47(23.5 \%)$ & 22 (46.8\%) & $25(53.2 \%)$ & & \\
\hline Extended joint & $23(11.5 \%)$ & 09 (39.1\%) & $14(60.9 \%)$ & & \\
\hline
\end{tabular}

In our study we noted that according to Socio-economic status, about 78 (39\%) girls belonged to class IV next being 55 (27.5\%) belonging to class III, combining class III- IV was only $41.7 \%$ were anemia, only class V had 12 i.e., $46.2 \%$, significant $\mathrm{P}$ value is found, which indicated high prevalence of anemia is more among Lower class followed by upper lower class. Majority of the girls, $130(65 \%)$ belonged to nuclear families, $47(23.5 \%)$ to joint families and $23(11.5 \%)$ to extended joint families, and $\mathrm{P}$ value was not found statistically significant.

Table 4: Comparison of parent's education with anemia

\begin{tabular}{ccccccc}
\hline Parameters & \multicolumn{3}{c}{ Father } & \multicolumn{3}{c}{ Mother } \\
\hline $\mathrm{N}=200$ & Illiterate & Literate & P value & Illiterate & Literate & P Value \\
& $\mathrm{N}=38$ & $\mathrm{~N}=162$ & & $\mathrm{~N}=186$ & $\mathrm{~N}=14$ & \\
\hline Anemia (50) & $16(32 \%)$ & $34(68 \%)$ & 0.034 & $42(84 \%)$ & $8(16 \%)$ & 0.230 \\
No Anemia (150) & $22(14.6 \%)$ & $128(85.4 \%)$ & 0.052 & $144(96 \%)$ & $6(4 \%)$ & 0.023 \\
\hline
\end{tabular}

In our study 50 cases were anemic among these $16(32 \%)$ had illiterate father compared to $34(68 \%)$ literate father with $p$ value 0.034 (which is not statically significant), but majority of them, that is $42(84 \%)$ had illiterate mother and only $8(16 \%)$ had literate mother. This signifies that mother's education plays an important role in prevalence of adolescent students' anemia, as she is directly involved in managing the nutritious status of adolescent's girls however $\mathrm{p}$ value was not statically significant. In case of 150 non- anemia cases $128(85.4 \%)$ father were literate and $6(4 \%)$ mother were Literate, signifies that father education may also play role in prevention of anemia, might be by affecting the economic status of the family.

Overall, both parent's education signifies the nutritious status of adolescent girls by influencing both economic and nutritional status.

\section{DISCUSSION}

The prevalence of anemia in the present study was $25 \%$, which is similar to the prevalence in developing countries (27\%). ${ }^{9}$ Many other studies have showed varying prevalence of anemia in India. Chandrakumari, et al. $(2019)^{10}$ found a prevalence of $48.63 \%$ among adolescent girls in a rural area of Tamil Nadu. Patil N et al.. (2018) ${ }^{11}$ found that the overall prevalence of anemia was $44.4 \%$ among adolescent girls in North Karnataka. Melwani V et al..(2018) $)^{12}$ reported that anemia was present in $57.65 \%$ girls amongst adolescent girls residing in slum of Bhopal city. Ayushi Agrawal et, al.(2018) ${ }^{13}$ reported a prevalence of $45.7 \%$ among adolescent girls in a coastal district of India. Patel S, Dhuppar P, Bhattar A (2017) ${ }^{14}$ conducted a study on nutritional anemia status in adolescent girls in rural schools of Raipur and found a 36.4\% prevalence of anemia. The 15 evalence of anemia was $36.59 \%$ in a study conducted by Gurpreet Singh, Kuldip Singh (2017) ${ }^{46}$ in urban college going girl students, whereas in a study by Bhagyalaxmi Sidenur, Gowri Shankar $(2017)^{16}$, anemia was present in $89 \%$ of adolescent girls. Mean age of the study participants in the present study was $16.65 \pm 1.96$ years. In a study by Patil $\mathrm{N}$ et al. ${ }^{11}$ mean age were $14.34 \pm 1.8$ years. Another study by Melwani V et al. ${ }^{12}$ in Bhopal city showed that mean age of the study participants was $15.2 \pm 2.5$ years. In the present study, prevalence was significantly more in girls belonging to lower socio economic class, $12(46.2 \%)$ compared to other socio economic groups. Also, the higher the socio - economic class, the lower was the prevalence of anemia $\left(\chi^{2}=14.281\right.$, $\mathrm{p}=0.006)$. The reason for this could be the availability of 
better quality of food in higher socioeconomic classes. This is in consistence with a study by Chandrakumari, et $a l .,{ }^{10}$ which showed that the prevalence of anemia was significantly high $(70.59 \%)$ among the girls who belonged to class V, followed by class IV (50.49\%) and class III (34.48\%), similarly, a study by Arya AK, Lal P, Kumar N, Barman S. ${ }^{17}$ showed that higher percentage of anemia was found in lower socio - economic class $(85.3 \%)$ and upper lower class $(83.3 \%)$. No participant belonged to upper class in the study. Even in a study by Srivastava A, Kumar $\mathrm{R}$, Sharma $\mathrm{M},{ }^{18}$ anemia was found to be significantly associated with low socioeconomic status, increased family size and lower levels of parental education.

\section{CONCLUSION}

$25 \%$ prevalence is noted in our study which is of moderate magnitude. Moderate anemia was most commonly found in our study that is $74 \%$. On peripheral smear, most commonly microcytic hypochromic anemia $60 \%$ was noted followed by normocytic normochromic 30\%, macrocytic normochromic $10 \%$. High risk factors were students belonging to low socio - economic groups

\section{REFERENCES}

1. World Health organization. Adolescent health and development. Available at: http://www.searo.who.int/en/Section13/Section1245_498 0.htm (last accessed on October 10, 2012).

2. United Nations, Department of economic and social affairs, population division, world population prospects: The 2008 revision. Available at: http://www.esa.un.org/unpd/wpp2008/index.htm (last accessed on October 12, 2012).

3. The state of the world's children 2011 - Adolescence an age of opportunity. UNICEF. Available at: http://www.unicef.org (last accessed on October 10, 2012).

4. World Health Organization. Programming for adolescent health and development. WHO Tech Rep Ser No. 886, 1996. p. 2.

5. Operational framework, Weekly iron and folic acid supplementation Program for adolescents - MOHFW. Available at http://www.mohfw.org (last accessed on September 5, 2012).
6. Tesfaye et al.. Anemia and iron deficiency among school adolescents: burden, severity, and determinant factors in southwest Ethiopia. Adolescent Health, Medicine and Therapeutics 2015:6 189-196

7. De LM, Pena-Rosas RJP, Cusick S, et al.. Hemoglobin Concentrations for the Diagnosis of Anemia and Assessment of Severity; Vitamin and Mineral Nutrition Information System. Vol 11. Geneva: World Health Organization; 2011:1.

8. Benoist $\mathrm{BD}$, McLean E, Egli I, et al.. Worldwide Prevalence of Anemia 1993-2005. Geneva: World Health Organization; 2008.

9. Balc YI, Karabulut A, Gürse D, et al.. Prevalence and risk factors of anemia among adolescents in Denizli, Turkey. Iran J Pediatr. 2012;22(1): 77-81.

10. Chandrakumari AS, Sinha P, Singaravelu S, Jaikumar S. Prevalence of anemia among adolescent girls in a rural area of Tamil Nadu, India. J Family Med Prim Care 2019;8:1414-7.

11. Patil $\mathrm{N}$ et al.. Prevalence of anemia among adolescent girls in a North Karnataka school: a cross sectional study. Int J Community Med Public Health. 2018 Dec;5(12):53605364

12. Melwani $\mathrm{V}$ et al.. A study to assess the prevalence of anemia amongst adolescent girls residing in selected slum of Bhopal city Int J Community Med Public Health. 2018 Mar;5(3):1096-1099

13. Ayushi Agrawal et, al. Anemia among Adolescents in a Coastal District of India. National Journal of Community Medicine | Volume 9 | Issue 6 | June 2018: 396-401

14. Patel S, Dhuppar P, Bhattar A (2017) Nutritional Anemia Status in Adolescent Girls in Rural Schools of Raipur, India. Med Chem (Los Angeles) 7: 853-856. doi: 10.4172/2161-0444.1000441

15. Gurpreet Singh, Kuldip Singh. Prevalence of anemia in urban college going girl students. Biomed Res- India 2017 Volume28 (3): 1040-1042

16. Bhagyalaxmi Sidenur, Gowri Shankar. A cross sectional study of anemia among adolescent girls in a Women's College in Bagalkot, Karnataka. Indian Journal of Forensic and Community Medicine, July-September 2017;4(3):167-170

17. Arya AK, Lal P, Kumar N, Barman S. Prevalence of anemia among adolescent girls in an urban slum of Kanpur, Uttar Pradesh. Int J Med Sci Public Health 2017;6(9):1378-1381.

18. Srivastava A, Kumar R, Sharma M. Nutritional anaemia in adolescent girls: an epidemiological study. Int $\mathrm{J}$ Community Med Public Health 2016;3:808-12.

Source of Support: None Declared
Conflict of Interest: None Declared

Policy for Articles with Open Access:

Authors who publish with MedPulse International Journal of Gynaecology, (Print ISSN: 2579-0870) (Online ISSN: 2636-4719) agree to the following terms: Authors retain copyright and grant the journal right of first publication with the work simultaneously licensed under a Creative Commons Attribution License that allows others to share the work with an acknowledgement of the work's authorship and initial publication in this journal.

Authors are permitted and encouraged to post links to their work online (e.g., in institutional repositories or on their website) prior to and during the submission process, as it can lead to productive exchanges, as well as earlier and greater citation of published work. 